\title{
Development of an Enzyme-linked Immuno-Sorbent Assay (ELISA) Method for Carbofuran Residues
}

\author{
Jinyi Yang ${ }^{1}$, Hong Wang ${ }^{1}$, Yueming Jiang ${ }^{2}$, Yuanming Sun ${ }^{1, *}$, Ke Pan ${ }^{1}$, Hongtao Lei $^{1}$, Qing \\ $\mathrm{Wu}^{1}$, Yudong Shen ${ }^{1}$, Zhili Xiao ${ }^{1}$ and Zhenlin $\mathrm{Xu}{ }^{1}$ \\ ${ }^{1}$ College of Food Science, South China Agricultural University, Guangzhou 510642, P. R. China; E- \\ mails: yjy361@163.com; gzwhongd@163.com; xiaopan412@163.com; hongtao@scau.edu.cn; \\ wuqingq@263.net; shenyudong@scau.edu.cn; scau_xzl@163.com; jallent@163.com \\ 2 South China Botanical Garden, Chinese Academy of Sciences, Guangzhou 510650, P. R. China; E- \\ mail: ymjiang@scbg.ac.cn
}

* Author to whom correspondence should be addressed; E-mail: ymsun@scau.edu.cn

Received: 27 March 2008; in revised form: 14 April 2008 / Accepted: 14 April 2008 / Published: 17 April 2008

\begin{abstract}
The haptens 4-[[(2,3-dihydro-2,2-dimethyl-7-benzofuranyloxy)carbonyl]amino]butanoic acid (BFNB) and 6-[((2,3-dihydro-2,2-dimethyl-7-benzofuranyloxy)carbonylamino]hexanoic acid (BFNH) were synthesized and then used to develop a rapid, specific and sensitive ELISA method to determine residues of the pesticide carbofuran in a variety of matrices. A hybridoma cell line (5D3) producing anti-carbofuran monoclonal antibodies (MAbs) was also established. Based on the MAbs in combination with the heterologous hapten BFNH coupled to either horseradish peroxidase (HRP) or ovalbumin (OVA), four ELISAs (formats I-IV) for the quantification of carbofuran were developed and compared. Among them, the optimized format II (the conjugate-coated direct competitive ELISA) showed the best characteristics, with an $\mathrm{IC}_{50}$ value of $18.49 \mathrm{ng} / \mathrm{mL}$, a limit of detection of $0.11 \mathrm{ng} / \mathrm{mL}$ and the shortest assay time $(1 \mathrm{~h})$. This ELISA method was then applied to the determinations of carbofuran in environmental water, soil and food samples. The relative standard deviations (R.S.D.s) ranged from $1.8 \%$ to $21.3 \%$ and the mean recoveries were $104.6 \%, 108.3 \%, 106.3 \%$ and $100.1 \%$ for water, soil, lettuce and cabbage, respectively. Thus, the ELISA method of format II exhibited the potential to develop commercial ELISA kits for a rapid detection of carbofuran for human health and environmental safety.
\end{abstract}


Keywords: Carbofuran, monoclonal antibodies (MAbs), enzyme-linked immuno-sorbent assay (ELISA)

\section{Introduction}

Carbofuran (2,3-dihydro-2,2-dimethyl-7-benzofuranylmethyl carbamate) is a pesticide widely and effectively used to control insects, but it is a potent cholinesterase inhibitor and thus exhibits a high toxicity to human beings and wildlife. Because of its widespread use carbofuran residues are potential air, soil, water and food pollutants [1,2]. In recent years, some assays such as gas-chromatography (GC), electro-chromatography, high-performance liquid chromatography (HPLC) and immunoassay $[3,4]$ have been developed to detect carbofuran residues present in water or foods. Among these assays, the HPLC method with post-column derivatization and fluorescence detection is currently the preferred one $[5,6]$, but the method requires specialized instrumentation and is time-consuming.

Recently, attention has been paid to the enzyme-linked immunosorbent assay (ELISA) as an analytical technique in the agrochemical field as it provides analytical chemists with a rapid and sensitive method [7-9]. Liu et al. [10] and Zhu et al. [11] have reported an immunoassay method to detect carbofuran residues, but the antibodies used were polyclonal, which had the deficiencies of limited specificity, affinity and purity. Abad et al. [12-14] developed an ELISA method for detecting carbofuran residues based on monoclonals and applied it to analyze fruit and vegetable samples, but they only used one or two ELISAs, and the detection limit for carbofuran was only $10 \mathrm{ng} / \mathrm{mL}$, a because of this relatively high detection limit it was unsuitable as an analytical method for developing a commercial ELISA kit for the sensitive detection of carbofuran residues. In this study, special monoclonal antibodies (MAbs) were produced and four ELISAs for detecting carbofuran residue were developed. The best ELISA was selected by comparing the four different formats and it was then applied to determine carbofuran residues in water, soil, lettuce and cabbage samples.

\section{Results and Discussion}

\section{Antigen synthesis}

The haptens 6-[((2,3-dihydro-2,2-dimethyl-7-benzofuranyloxy)carbonylamino]hexanoic acid (BFNH) and 4-[((2,3-dihydro-2,2-dimethyl-7-benzofuranyloxy)carbonylamino]butanoic acid (BFNB) were synthesized by a literature method [13] (Scheme 1). The products were characterized by their ${ }^{1} \mathrm{H}-$ NMR spectra, which matched the reported data [13].

These haptens were then covalently attached to bovine serum albumin (BSA) using the modified active ester method [15]. The UV-vis spectra showed the qualitative differences between the carrier protein and conjugate in the maximum absorbance regions of the haptens. 
Scheme 1. Synthesis of the carbofuran haptens BFNB and BFNH.

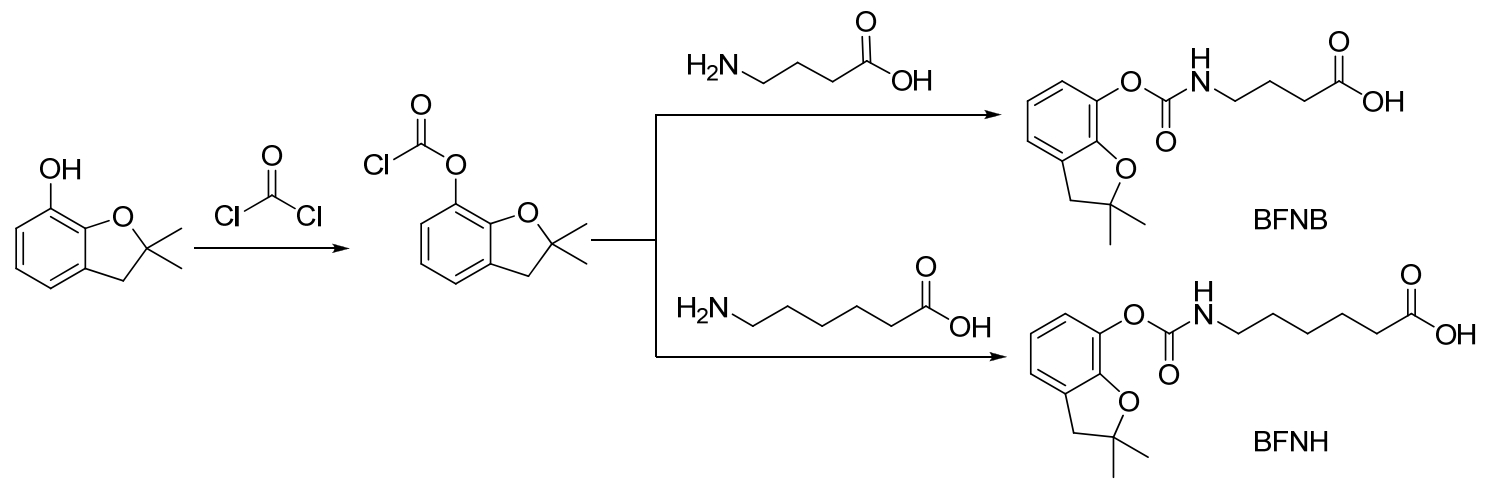

The hapten to protein molar ratio can be estimated from the spectral data. As the molar absorptivity of haptens was the same for the free and conjugated forms, the apparent molar ratios were estimated as 20 and 13 for the haptens BFNH and BFNB, respectively. After evaluation of the additive absorbance values, the molar ratios of haptens to protein were evaluated as 5 and 3 for BFNH and BFNB, respectively, based on the covalently attachment of the haptens to ovalbumin (OVA) [16].

\section{Preparation and purification of MAbs}

A hybridoma cell line (5D3) producing anti-carbofuran MAbs was established. The titres of culture medium and ascites were up to $1: 2.048 \times 10^{3}$ and $1: 1.024 \times 10^{6}$, respectively. The MAbs were then purified by saline precipitation with saturated ammonium sulfate. The concentration of obtained MAbs was $1.135 \mathrm{mg} / \mathrm{mL}$.

\section{Preparation of antibody-HRP}

The MAbs were covalently attached to HRP using the periodate oxidation method [17] and then the conjugate was determined by UV spectrophotometry. The $\mathrm{OD}_{403 \mathrm{~nm}}$ and $\mathrm{OD}_{280 \mathrm{~nm}}$ values were determined to be 0.297 and 0.658 , respectively. The molar ratio of HRP to antibody (E/P) was 1.35. The E/P was reported to be suitable for further used when it was between 1 and 2 [17].

\section{Evaluation of four ELISA formats}

On the basis of the use of the MAbs together with BFNH-OVA, BFNH-HRP and Antibody-HRP conjugates, four immunoassay formats (Format I-IV) were developed. The four ELISAs were established as a result of an optimization process, which included a study of the concentration of MAbs and the conjugates, the temperature and time. The inhibition curves of four ELISAs to carbofuran are shown in Figure 1 and their characteristics were summarized in Table 1. The most prominent findings of this study were the BFNH-OVA coated format ELISAs (format I and format II) produced a highly sensitive assay. The analytical characteristics of the immunoassays listed in Table 1 were estimated from the standard curves depicted in Figure 1. The limit of detection, estimated as the analyte concentration giving a 10\% inhibition, and the assay working range, calculated as the analyte 
concentrations providing a $20-80 \%$ inhibition, were very different for the four ELISA formats. This fact is clearly shown in Table 1 . Among them, format I exhibited the best sensitivity and limit of detection, but it required more steps and took longer A favorable ELISA format requires both good sensitivity and limit of detection, and should involve less steps and be time saving $[18,19]$, so on this basis the format II was determined to be the best one, with an $\mathrm{IC}_{50}$ value, a limit of detection and duration being $18.49 \mathrm{ng} / \mathrm{mL}, 0.11 \mathrm{ng} / \mathrm{mL}$, and $1 \mathrm{~h}$, respectively. It was deemed suitable for preparation of the commercial ELISA kits for detection of carbofuran residues.

Figure 1. Carbofuran inhibition curves using the four test formats.

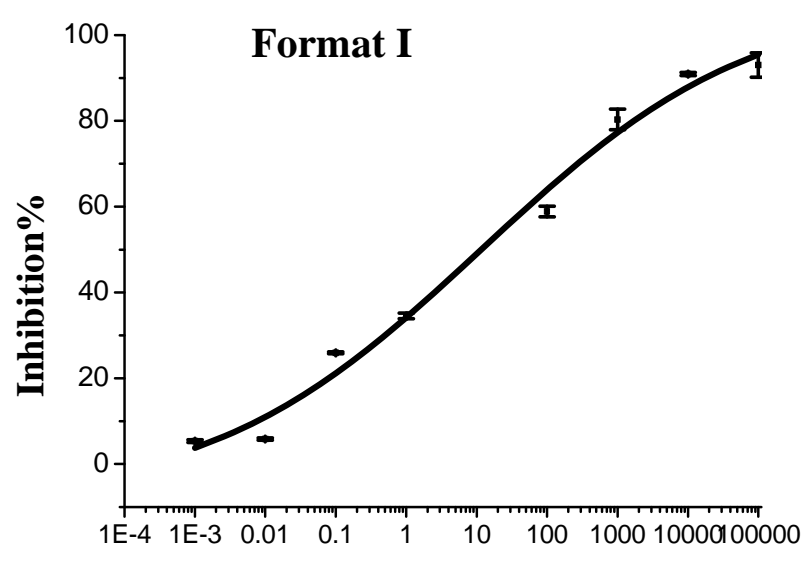

[CARBOFURAN] (ng/mL)

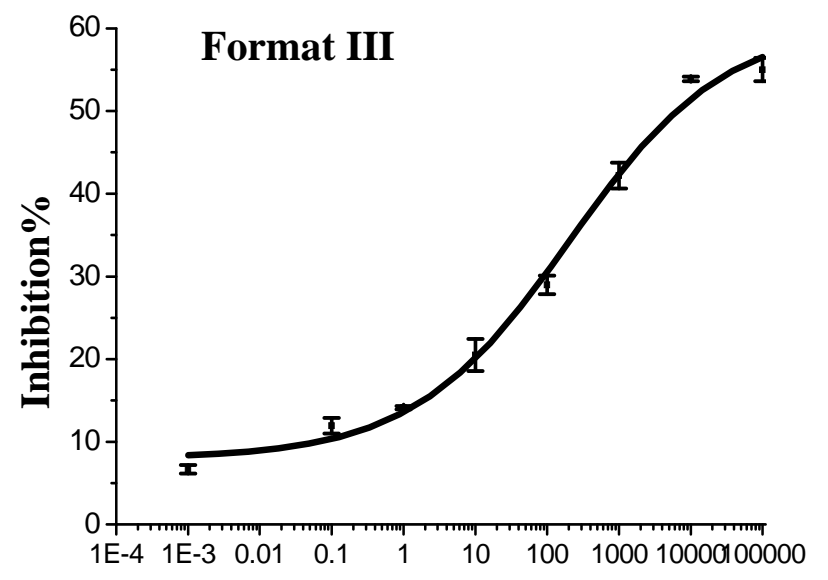

[CARBOFURAN] (ng/mL)

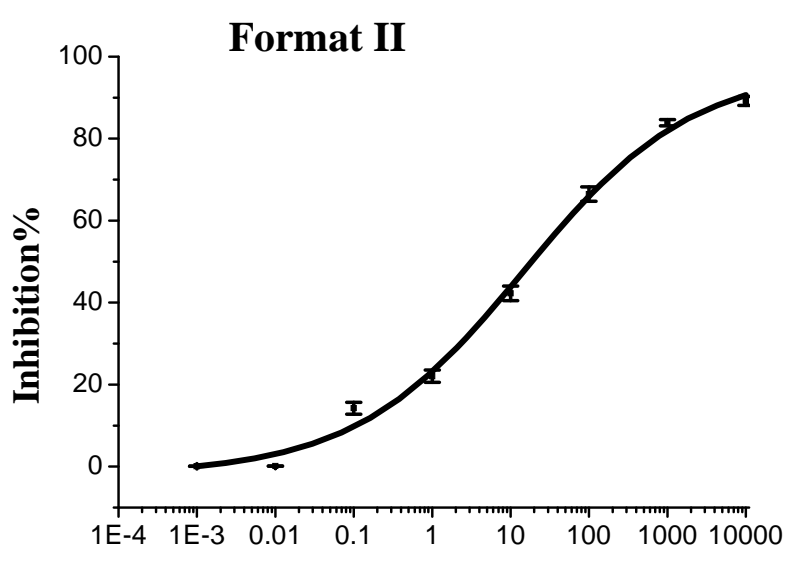

[CARBOFURAN] (ng/mL)

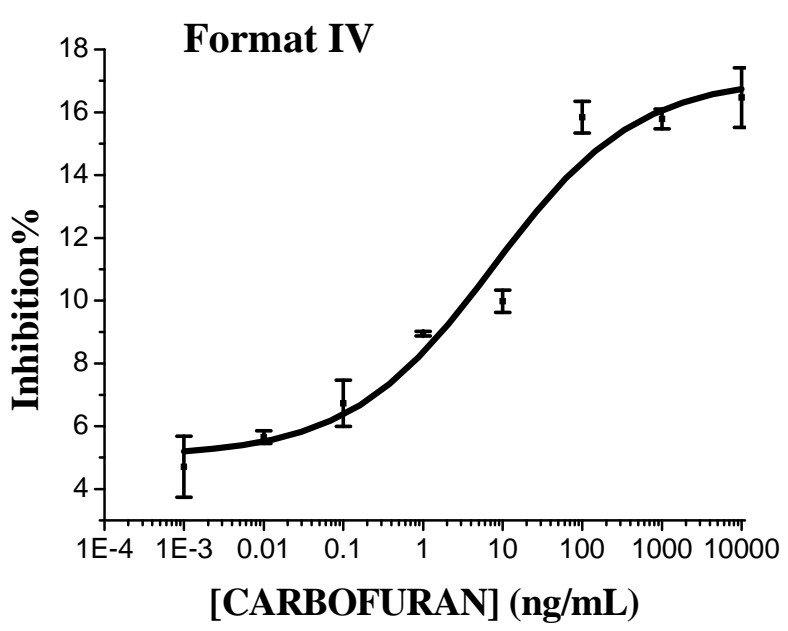

Differences between the four ELISA formats

The study showed that formats I and II were better than formats III and IV because the number of the HRP-hapten conjugates recognized by immobilized antibodies was lower than the number of OVA-hapten conjugates recognized [20,21]. Moreover, hapten with a large spacer arm and with short linking groups exhibited less suitability for enzyme conjugates, probably due to steric hindrances [2224]. 
Table 1. A summary of the four carbofuran immunoassays.

\begin{tabular}{|c|c|c|c|c|}
\hline \multirow{2}{*}{ Parameter } & \multicolumn{4}{|c|}{ Format } \\
\hline & Format I & Format II & Format III & Format IV \\
\hline $\begin{array}{l}\text { BFNH-OVA } \\
(\mathrm{ng} / \mathrm{mL})\end{array}$ & 0.5 & 0.25 & - & - \\
\hline MAbs (ng/mL) & 0.057 & - & 0.35 & 1.42 \\
\hline $\begin{array}{c}\text { The secondary } \\
\text { antibody }\end{array}$ & $\begin{array}{c}\text { Peroxidase- } \\
\text { labeled goat anti- } \\
\text { mouse } \\
\text { immunoglobulins } \\
\text { diluted } 1: 20000\end{array}$ & - & - & $\begin{array}{c}1 \mu \mathrm{g} / \mathrm{mL} \\
\text { Goat anti-mouse } \\
\text { immunoglobulins }\end{array}$ \\
\hline Antibody-HRP & - & $1: 80$ & - & - \\
\hline BFNH-HRP & - & - & $1: 800$ & $1: 400$ \\
\hline Step & 5 & 3 & 3 & 4 \\
\hline $\begin{array}{l}\text { Assay time } \\
\text { (h) }\end{array}$ & 4 & 1 & 1.5 & 2 \\
\hline $\mathrm{IC}_{50}(\mathrm{ng} / \mathrm{mL})$ & 11.63 & 18.49 & 6343.38 & $>10000$ \\
\hline $\begin{array}{c}\text { Limit detection } \\
(10 \% \text { inhibition }) \\
(\mathrm{ng} / \mathrm{mL})\end{array}$ & 0.007 & 0.11 & 0.066 & 3.58 \\
\hline $\begin{array}{c}\text { Linearity } \\
\text { detection range } \\
(\mathrm{ng} / \mathrm{mL})\end{array}$ & $\begin{array}{c}\mathrm{IC}_{20}-\mathrm{IC}_{80} \\
0.08-1694.93\end{array}$ & $\begin{array}{c}\mathrm{IC}_{20}-\mathrm{IC}_{80} \\
0.65-692.64\end{array}$ & $\begin{array}{c}\mathrm{IC}_{20}-\mathrm{IC}_{50} \\
9.82-6343.38\end{array}$ & $\begin{array}{c}\mathrm{IC}_{8}-\mathrm{IC}_{15} \\
0.74-188.92\end{array}$ \\
\hline
\end{tabular}

— Not applicable

\section{Sample analysis}

Water, soil, lettuce and cabbage samples were spiked with carbofuran at $0.1,1,10$ and $50 \mathrm{ng} / \mathrm{mL}$ and directly analyzed by ELISA (Format II). The results were summarized in Table 2. The mean recoveries for water, soil, lettuce and cabbage juices were $104.6 \%, 108.3 \%, 106.3 \%$ and 100.1\%, respectively. The R.S.D.s were ranging from $1.8 \%$ to $21.3 \%$. The recoveries and precisions obtained for the four samples can be considered good for a residue detected method. In this study, the samples without carbofuran were used as the negative control.

\section{Conclusions}

In this study a conjugate-coated direct competitive ELISA (format II) for detecting carbofuran, with an $\mathrm{IC}_{50}$ value of $18.49 \mathrm{ng} / \mathrm{mL}$ and a limit of detection of $0.11 \mathrm{ng} / \mathrm{mL}$, was developed. The ELISA was applied to determine carbofuran residues in water, soil, lettuce and cabbage samples. The R.S.D.s ranged from $1.8 \%$ to $21.3 \%$ and the mean recoveries were $104.6 \%, 108.3 \%, 106.3 \%$ and $100.1 \%$ for water, soil, lettuce and cabbage, respectively. Thus, the ELISA method of format II exhibited the potential to develop commercial ELISA kits for a sensitive and rapid detection of carbofuran residue. 
Table 2. Analyses of carbofuran in water, soil, lettuce and cabbage samples by ELISA $(n=3)$.

\begin{tabular}{|c|c|c|c|c|}
\hline Matrix & $\begin{array}{c}\text { Fortification } \\
\text { Level (ng/mL) }\end{array}$ & $\begin{array}{c}\text { Mean } \pm \text { S.D. } \\
(\mathrm{ng} / \mathrm{mL})\end{array}$ & $\begin{array}{c}\text { Recovery } \\
(\%) \\
\end{array}$ & R.S.D. (\%) \\
\hline \multirow{5}{*}{ Lettuce } & 0.1 & $0.14 \pm 0.03$ & 140.0 & 14.7 \\
\hline & 1 & $0.93 \pm 0.04$ & 93.0 & 12.8 \\
\hline & 10 & $9.71 \pm 0.11$ & 97.1 & 5.9 \\
\hline & 50 & $47.6 \pm 0.93$ & 95.2 & 12.2 \\
\hline & Means & & 106.3 & 11.4 \\
\hline \multirow{5}{*}{ Cabbage } & 0.1 & $0.12 \pm 0.02$ & 120.0 & 13.9 \\
\hline & 1 & $0.87 \pm 0.06$ & 87.0 & 13.7 \\
\hline & 10 & $9.80 \pm 0.25$ & 98.0 & 6.4 \\
\hline & 50 & $47.6 \pm 1.02$ & 95.2 & 21.3 \\
\hline & Means & & 100.1 & 13.8 \\
\hline \multirow{5}{*}{ Water } & 0.1 & $0.13 \pm 0.01$ & 130.0 & 7.7 \\
\hline & 1 & $0.96 \pm 0.078$ & 96.0 & 8.1 \\
\hline & 10 & $9.42 \pm 0.17$ & 94.2 & 1.8 \\
\hline & 50 & $49.18 \pm 4.35$ & 98.4 & 8.8 \\
\hline & Means & & 104.6 & 6.6 \\
\hline \multirow{5}{*}{ Soil } & 0.1 & $0.13 \pm 0.02$ & 130.0 & 15.6 \\
\hline & 1 & $1.07 \pm 0.11$ & 107.0 & 10.4 \\
\hline & 10 & $9.88 \pm 0.88$ & 98.8 & 8.9 \\
\hline & 50 & $48.69 \pm 5.72$ & 97.4 & 11.7 \\
\hline & Means & & 108.3 & 11.6 \\
\hline
\end{tabular}

\section{Experimental}

\section{Materials}

Analytical pesticide standards were obtained from Shennong Jiangsu Chemistry Co. The BSA and OVA were purchased from Sigma-Aldrich. Enzyme immunoassay grade HRP, peroxidase labelled rabbit anti-mouse immunoglobulins and rabbit anti-mouse immunoglobulins were obtained from Wuhan Boster Biotech Co. All other chemicals and organic solvents were of reagent grade. Polystyrene ELISA plates were from Guangzhou Jiete Biotech Co. and treated with a Multiskan MK2 microplate washer (Thermo Labsystems). Absorbances were read with a Multiskan MK3 microplate reader (Thermo Labsystems). Ultraviolet-visible (UV-vis) spectra were recorded on a UV-160A Shimadzu spectrophotometer (Kyoto, Japan). ${ }^{1} \mathrm{H}-\mathrm{NMR}$ spectra were obtained on a DRX-400 NMR spectrometer (Bruker, Germany-Switzerland).

Antigen synthesis

Hapten synthesis [13]. 2,3-Dihydro-2,2-dimethyl-7-benzofuranol was reacted with a slight excess of phosgene at $25^{\circ} \mathrm{C}$ for $4 \mathrm{~h}$ to give 2,3-dihydro-2,2-dimethyl-7-benzofuranyl chloroformate (DDBC), 
which was subsequently used without further purification. After the crude DDBC (7.14 g, $31.4 \mathrm{mmol})$ reacted for $1.5 \mathrm{~h}$ with aminocaproic acid $(4.60 \mathrm{~g}, 35.1 \mathrm{mmol})$ or aminobutyic acid $(3.62 \mathrm{~g}, 35.1 \mathrm{mmol})$, the precipitated product was collected, then washed with water, and finally dried to yield crude 6[((2,3-dihydro-2,2-dimethyl-7-benzofuranyloxy)carbonylamino]hexanoic acid (BFNH, $7.8 \mathrm{~g}, 66 \%$ yield) or 4-[((2,3-dihydro-2,2-dimethyl-7-benzofuranyloxy)carbonylamino] butanoic acid (BFNB, 5.6 g, 52\% yield), which were recrystallized from hexane/ethyl acetate (70:30) to yield the pure haptens, whose identities were confirmed by their NMR spectra. BFNH: ${ }^{1} \mathrm{H}-\mathrm{NMR}: \delta 1.42\left(\mathrm{~s}, 6 \mathrm{H}, 2 \mathrm{CH}_{3}\right)$, 1.41-1.63 (m, 6H, $\mathrm{CH}_{2} \mathrm{CH}_{2} \mathrm{CH}_{2}$ ), 2.25-2.29 (t, 2H, $\left.\mathrm{CH}_{2} \mathrm{COOH}\right), 3.02$ (s, 2H, $\left.\mathrm{CH}_{2}\right), 3.15-3.20(\mathrm{q}, 2 \mathrm{H}$, $\left.\mathrm{CH}_{2} \mathrm{NH}\right)$ and 6.70-6.96 (m, 3H, aromatic)]; BFNB: ${ }^{1} \mathrm{H}-\mathrm{NMR}: \delta 1.40\left(\mathrm{~s}, 6 \mathrm{H}, 2 \mathrm{CH}_{3}\right), 1.83\left(\mathrm{~m}, 2 \mathrm{H}, \mathrm{CH}_{2}\right)$, 2.39 (t, 2H, $\left.\mathrm{CH}_{2} \mathrm{COOH}\right), 3.01\left(\mathrm{~s}, 2 \mathrm{H}, \mathrm{CH}_{2}\right), 3.23\left(\mathrm{q}, 2 \mathrm{H}, \mathrm{CH}_{2} \mathrm{NH}\right)$ and 6.69-6.96 (m, 3H, aromatic)]. These results were a good match the data reported by Abad et al. [13], confirming the successful synthesis of both compounds.

Preparation of immunizing conjugates. The haptens BFNB and BFNH were covalently attached to BSA by the modified active ester method [15] and the resulting conjugates were determined by UV spectrophotometry. The molar ratio of hapten to protein was calculated by the method of Chen et al. [16].

Preparation of coating conjugates. The haptens BFNB and BFNH were covalently attached to OVA using the mixed-anhydride method [15], and were determined as mentioned above.

\section{Production of MAbs to carbofuran}

BALB/c female mice (8-10 weeks old) were immunized with BFNB-BSA conjugates. The splenocytes of immunized mice were fused with Sp2/0 cells using PEG 1500 as the fusing agent. The culture supernatant of hybridoma cells was screened to determine the presence of antibodies that recognize carbofuran. The screening consisted of the simultaneous performance of noncompetitive and competitive indirect ELISAs, to test the ability of antibodies to bind the OVA conjugate of the immunizing hapten and to recognize carbofuran, respectively. The selected hybridomas were cloned by the micrurgical technique. Stable antibody-producing clones were expanded and cryopreserved in liquid nitrogen.

\section{Purification of MAbs}

The hybridomas were collected after centrifugation and then suspended in the culture media without fetal bovine serum. The BALB/c female mice received a soluble intraperitoneal injection at a dose of $0.5 \mathrm{~mL}$ and a cell concentration of $1 \times 10^{6} / \mathrm{mL}$ to $2 \times 10^{6} / \mathrm{mL}$. The ascites were abstracted after two weeks. The antibodies were purified by saline precipitation with $45 \%$ saturated ammonium sulfate and the concentration of antibodies was then determined by spectrophotometry. 


\section{Preparation of antibody-HRP}

The MAbs were covalently attached to HRP using the periodate oxidation method [17]. The HRP $(5 \mathrm{mg})$ was dissolved in distilled water $(1 \mathrm{~mL})$ and sodium periodate $(0.1 \mathrm{~mol} / \mathrm{L})$ was then added. The reaction was incubated at $25^{\circ} \mathrm{C}$ for $20 \mathrm{~min}$. The product was dialysed at $4{ }^{\circ} \mathrm{C}$ for $12 \mathrm{~h}$ with sodium acetate buffer $(1 \mathrm{mmol} / \mathrm{L})$ at $\mathrm{pH} 4.0$. The antibody was diluted to $10 \mathrm{mg} / \mathrm{mL}$ with sodium carbonate buffer $(\mathrm{pH} 9.5,0.1 \mathrm{~mol} / \mathrm{L})$. The $\mathrm{pH}$ value of the actived HRP was then adjusted to 9.5 with sodium carbonate buffer $(\mathrm{pH} 9.5,0.1 \mathrm{~mol} / \mathrm{L})$. The antibody $(0.5 \mathrm{~mL})$ was added to the HRP solution and the mixture was then allowed to react at $25^{\circ} \mathrm{C}$ for $2 \mathrm{~h}$. Sodium borate $(4 \mathrm{mg} / \mathrm{mL})$ was added and reacted at $4{ }^{\circ} \mathrm{C}$ for $2 \mathrm{~h}$. Finally, the product was dialysed with $0.1 \mathrm{~mol} / \mathrm{L}$ sodium phosphate buffer $(\mathrm{pH} 7.4)$. The conjugate was determined by UV spectrophotometry. The molar ratio of HRP to antibody (E/P) was calculated as follows:

$$
\begin{aligned}
& \mathrm{HRP}(\mathrm{mg} / \mathrm{mL})=\mathrm{OD}_{403 \mathrm{~nm}} \times 0.4 \\
& \mathrm{IgG}(\mathrm{mg} / \mathrm{mL})=\left(\mathrm{OD}_{280 \mathrm{~nm}}-\mathrm{OD}_{403 \mathrm{~nm}} \times 0.3\right) \times 0.62 \\
& \mathrm{E} / \mathrm{P}=(\mathrm{HRP} \times 4) / \mathrm{IgG}
\end{aligned}
$$

\section{Preparation of BFNH-HRP}

The hapten BFNH was covalently attached to HRP using the mixed-anhydride method mentioned above.

\section{Preparation of standard solutions}

Standard solutions were prepared on glass tubes instead of the plastic tubes, since it was found that the plastic tubes adsorbed carbofuran. Standards from $2 \times 10^{-3}$ to $2 \times 10^{5} \mathrm{ng} / \mathrm{mL}$ were prepared by $1 / 10$ dilution in PBST $\left(8.03 \mathrm{mmol} \mathrm{Na}_{2} \mathrm{HPO}_{4}, 1.97 \mathrm{mmol} \mathrm{KH}_{2} \mathrm{PO}_{4}, 137 \mathrm{mmol} \mathrm{NaCl}, 2.68 \mathrm{mmol} \mathrm{KCl}\right.$, containing $0.05 \%$ Tween-20, $\mathrm{pH} 7.4$ ). The final carbofuran concentrations in the assay ranged from 1 $\times 10^{-3}$ to $1 \times 10^{5} \mathrm{ng} / \mathrm{mL}$.

The development of ELISAs for carbofuran

Flat-bottom polystyrene ELISA plates were coated overnight with conjugate solution of $50 \mathrm{mmol} / \mathrm{L}$ carbonate buffer ( $\mathrm{pH}$ 9.6). A volume of $50 \mu \mathrm{L}$ per well was used throughout all assay steps and all incubations were carried out at $37^{\circ} \mathrm{C}$.

Conjugate-coated indirect competitive ELISA (Format I). Plates were coated with BFNH-OVA conjugates of $0.5 \mathrm{ng} / \mathrm{mL}$ previously determined to be the optimal by checkerboard titration. Carbofuran standards $(50 \mu \mathrm{L})$ were added into the well and $50 \mu \mathrm{L}$ antibody $(0.057 \mathrm{ng} / \mathrm{mL})$ was added and then incubated for $2 \mathrm{~h}$. Finally, the plates were incubated for $1 \mathrm{~h}$ with peroxidase-labeled goat antimouse immunoglobulins diluted in PBST solution. Peroxidase activity bound to the wells was 
determined by adding the substrate solution $\left(2 \mathrm{mg} / \mathrm{mL}\right.$ o-phenylendiamine and $0.012 \% \mathrm{H}_{2} \mathrm{O}_{2}$ in 25 mmol citrate, $62 \mathrm{mmol}$ sodium phosphate, $\mathrm{pH} 5.4$ ). After $15 \mathrm{~min}$, the reaction was stopped with 2.5 $\mathrm{mol} / \mathrm{L}$ sulfuric acid. The absorbance was recorded at $490 \mathrm{~nm}$. Competitive curves were obtained by plotting the inhibition rate against the logarithm of carbofuran concentration. Sigmoidal curves were fitted to four-parameter logistic equation, using the Originpro 7.5 software package.

$$
\text { Inhibition rate }(\%)=\frac{A_{490 \max }-A_{490}}{A_{490 \max }} \times 100
$$

Conjugate-coated direct competitive ELISA (Format II). In this format, plates were coated with BFNH-OVA $(0.25 \mathrm{ng} / \mathrm{mL})$ conjugates. The competitive ELISA was established for $0.5 \mathrm{~h}$ between carbofuran standards and the selected concentration (1:80) of antibody-HRP. Peroxidase activity was measured using the method mentioned above.

First antibody-coated direct competitive ELISA (Format III). Plates were coated with antibody (0.35 $\mathrm{ng} / \mathrm{mL}$ ) for carbofuran. The competitive ELISA was established for $2 \mathrm{~h}$ between carbofuran standards and the selected concentration (1:800) of BFNH-HRP. Peroxidase activity was measured using the method mentioned above.

Second antibody-coated direct competitive ELISA (Format IV). Plates were coated with rabbit antimouse immunoglobulins $(1 \mu \mathrm{g} / \mathrm{mL})$. The selected concentration $(1.42 \mathrm{ng} / \mathrm{mL})$ of antibody for carbofuran was added and then incubated for $0.5 \mathrm{~h}$. The competitive ELISA was established for $1 \mathrm{~h}$ between carbofuran standards and the selected concentration (1:400) of BFNH-HRP. Peroxidase activity was measured using the method mentioned above.

\section{Preparation of samples}

Lettuce and cabbage samples were obtained from the market of the South China Agriculture University (SCAU) before use. The lettuce and cabbage juice samples were prepared with a fruit pulping machine and diluted 1:5 in PBS and then spiked with carbofuran at 0.1, 1, 10 and $50 \mathrm{ng} / \mathrm{mL}$. The water samples from pond and soil samples from vegetable plot were obtained from the campus of SCAU. The soil samples $(50 \mathrm{~g})$ were diluted with PBS $(50 \mathrm{~mL})$ and stirred for $12 \mathrm{~h}$. The clear supernatant was collected by centrifugation at 4,000 rpm for $10 \mathrm{~min}$. The soil supernatant and water samples were spiked with carbofuran at $0.1,1,10$ and $50 \mathrm{ng} / \mathrm{mL}$.

\section{Acknowledgements}

This work was supported by the National S\&T $10^{\text {th }}$ Five-Year Plan of China, Grant No. 2002BA518A06-04, Guangdong Province Key Project for Natural Science, Grant No. 036842, Guangzhou Key Project for Science and Technology, Grant Nos. 2004Z2-E0031 and 2004Z1-E0061, Natural Science Foundation of Guangdong Province, Grant No. 06300421, the National High-Tech 
Research, Development Program of China (863 Program), Grant No. 2006AA10Z447, and the Knowledge Innovation Program of the Chinese Academy of Sciences, Grant No. KSCX2-YW-N-036.

\section{References}

1. Tomlin, C.D.S. The Pesticide Manual: A World Compendium $11^{\text {th }}$ ed. British Crop Protection Publications: Surrey, UK, 1997; pp. 186-188.

2. Campbell, S; David, M.D.; Woodward, L.A.; Li, Q.X. Persistence of carbofuran in marine sand and water. Chemosphere 2004, 54, 1155-1161.

3. Richter, P.; Sepulveda, B.; Oliva, R.; Calderon, K.; Seguel, R. Screening and determination of pesticides in soil using continuous subcritical water extraction and gas chromatography-mass spectrometry. J. Chromatogr. A. 2003, 994, 169-177.

4. Caballo-López, A.; Luque de Castro, M.D. Continuous ultrasound-assisted extraction coupled to on line filtrationsolid-phase extraction-column liquid chromatography-post column derivatisationfluorescence detection for the determination of $\mathrm{N}$-methylcarbamates in soil and food. $J$. Chromatogr. A. 2003, 998, 51-59.

5. Mc Garvey, B.D. High-performance liquid chromatographic methods for the determination of Nmethylcarbamate pesticides in water, soil, plants and air. J. Chromatogr. A. 1993, 642, 89-105.

6. Yang, S.S.; Goldsmith, A.I.; Smetena, I. Recent advances in the residue analysis of Nmethylcarbamate pesticides. J. Chromatogr. A. 1996, 754, 3-16.

7. Anne, D.L.; Shirley, J.G.; Hammock, B. D. Integration of immunochemical methods with other analytical techniques for pesticides residue determination. J. AOAC. Int. 1995, 78, 585-588.

8. Mickova, B.; Zrostlikova, J.; Hajslova J.; Rauch, P.; Moreno, M.-J.; Abad, A.; Montoya, A. Correlation study of enzyme linked immunosorbent assay and high-performance liquid chromatography/tandem mass spectrometry for the determination of N-methylcarbamate insecticides in baby food. Anal. Chim. Acta 2003, 495, 123-132.

9. Li, K.; Li, Q.X. Development of an enzyme linked immunosorbent assay for the insecticide imidacloprid. J. Agric. Food Chem. 2000, 48, 3378-3382.

10. Liu, S.Z.; Feng, D.H.; Chen, M.J.; Qian, C.F. Study on a highly specific enzyme linked immunosorbent assay for carbofuran. J. Anal. Sci. 2000, 16, 373-378.

11. Zhu, G.N.; Yang, T.; Wu, Y.L. Development of anti-carbofuran antibodies. Sci. Agric. Sin. 2002, 35, 1025-1029.

12. Abad, A.; Moreno, M.J.; Montoya, A. A monoclonal immunoassay for carbofuran and its application to the analysis of fruit juices. Anal. Chim. Acta. 1997, 347, 103-110.

13. Abad, A.; Moreno, M.J.; Montoya, A. Development of monoclonal antibody based immuno assays to the Nmethylcarbamate pesticide carbofuran. J. Agric. Food Chem. 1999, 47, 2475-2485.

14. Abad, A.; Moreno, M.J.; Pelegr, R.; Martınez, M.I; Saez, A.; Gamon, M.; Montoya, A. Determination of carbaryl, carbofuran and methiocarb in cucumbers and strawberries by monoclonal enzyme immunoassays and highperformance liquid chromatography with fluorescence detection An analytical comparison. J. Chromatogr. A. 1999, 833, 3-12.

15. Hong, X.Z.; Sun, M.Q. The Technology of Protein Linking. China Medical Technology Press: Beijing, China, 1993; pp. 2-56. 
16. Chen, X.J.; Chen, M.Y.; Zhao, H.J. Application of Immunological Technology in Botany. China Agricultural University Press: Beijing, China, 1998; p. 45.

17. Shen, G.X.; Zhou, R.L. Modern Immunology Laboratory Technology. Science and Technology Press: Hubei, China, 1998; pp. 112-114.

18. Gabaldón, J.A.; Maquieira, A.; Puchades, R. Current trends in immunoassay-based kits for pesticide analysis. Crit. Rev. Food Sci. Nutr. 1999, 39, 519-538.

19. Crowther, J.R. The ELISA Guidebook. Humana Press: Totowa, New Jersey, USA, 2001; pp. 9-83.

20. Manclus, J.J.; Montoya, A. Development of an enzyme-linked immunosorbent assay for 3,5,6trichloro-2-pyridinol. 1. Production and characterization of monoclonal antibodies. J. Agric. Food Chem. 1996, 44, 3703-3709.

21. Manclus, J.J.; Montoya, A. Development of an enzyme-linked immunosorbent assay for 3,5,6trichloro-2-pyridinol. 2. Assay optimization and application to environmental water samples. $J$. Agric. Food Chem. 1996, 44, 3710-3716.

22. Skerritt, J.H.; Hill, A.S.; Beasley, H.L.; Edward, S.L.; McAdam, D.P. Enzyme-linked immunosorbent assay for quantitation of organophosphate pesticides: fenitrothion, chlorpyrifosmethyl, and pirimiphos-methyl in wheat grain and flour-milling fractions. J. AOAC Int. 1992, 75, 519-528.

23. Bekheit, H.K.M.; Lucas, A.D.; Szurdoki, F.; Gee, S.J.; Hammock, B.D. An enzyme immunoassay for the environmental monitoring of the herbicide bromacil. J. Agric. Food Chem. 1993, 41, 22202227.

24. Schneider, P.; Goodrow, M.H.; Gee, S.J.; Hammock, B.D. A highly sensitive and rapid ELISA for the arylurea herbicides diuron, monuron, and linuron. J. Agric. Food Chem. 1994, 42, 413-422.

Sample Availability: Available from the authors.

(C) 2008 by MDPI (http://www.mdpi.org). Reproduction is permitted for noncommercial purposes. 